\title{
Improving quality of common reed (Phragmites communis Trin.) silage with additives
}

\author{
Keigo Asano ${ }^{1, *}$, Takahiro Ishikawa', Ayako Araie ${ }^{1}$, and Motohiko Ishida ${ }^{1}$
}

* Corresponding Author: Keigo Asano Tel: +81-76-227-7438, Fax: +81-76-227-7410,

E-mail: asanok@ishikawa-pu.ac.jp

'Department of Bioproduction Science, Faculty of Bioresouces and Environmental Science, Ishikawa Prefectural University, Ishikawa 921-8824, Japan

ORCID

Keigo Asano

https://orcid.org/0000-0002-6575-6947

Submitted Oct 31, 2017; Revised Jan 22, 2018; Accepted Apr 2, 2018
Objective: Common reed (Phragmites communis Trin.) could potentially provide an alternative resource for silage; however, its silage quality is poor. The aim of this study was to investigate the factors in reed that contribute to poor quality and determine how the use of additives at ensiling could improve fermentation quality.

Methods: In Experiment 1, we determined the chemical composition and the presence of indigenous lactic acid bacteria (LAB) in reed. We further examined fermentation quality of reed silage under conditions without additives (NA) and treated glucose $(\mathrm{G})$, lactic acid bacteria (L), and their combination (G+L). In Experiment 2, silage of NA, and with an addition of cellulase and lactic acid bacteria (CL) were prepared from harvested reed. The harvested reeds were fertilized at nitrogen concentrations of $0,4,8$, and $12 \mathrm{~g} \mathrm{~N} / \mathrm{m}^{2}$ and were harvested thrice within one year.

Results: The indigenous LAB and fermentable carbohydrates are at extremely low concentrations in reed. Reed silage, to which we added $\mathrm{G}+\mathrm{L}$, provided the highest quality silage among treatments in Experiment 1. In Experiment 2, $\mathrm{N}$ fertilization had no negative effect on silage quality of reed. The harvest times decreased fermentable carbohydrate content in reed. The CL treatment provided a higher lactic acid content compared to the NA treatment. However, the quality of CL treated silage at the second and third harvests was significantly lower than at the first harvest, due to a reduction in carbohydrates caused by frequent harvesting.

Conclusion: The causes of poor quality in reed silage are its lack of indigenous LAB and fermentable carbohydrates and its high moisture content. In addition, reed managed by frequent harvesting reduces carbohydrate content. Although the silage quality could be improved by adding CL, higher-quality silage could be prepared by adding fermentable carbohydrates, such as glucose (rather than adding cellulases).

Keywords: Water-soluble Carbohydrate; Lactic Acid Bacteria; Cellulase; Harvest Times; Nitrogen Fertilization

\section{INTRODUCTION}

According to the Ministry of Agriculture, Forestry and Fisheries, based on total digestible nutrients, feed self-sufficiency in Japan was only 27\% in 2015 [1]. Increasing domestic feed production is a critical issue in Japan. The common reed (Phragmites communis Trin.) has been studied recently as a potential feed or bioenergy resource (due to its ability to produce high-yields of dry matter [DM] [2,3]) and for its potential for providing roughage for ruminants $[4,5]$. Furthermore, common reed is distributed widely in abandoned paddy fields and at riverside sites throughout Japan, most of them is burned or left useless, and so its utilization as animal feed could potentially improve Japan's feed self-sufficiency. The primary method of preserving forage is via hay or silage. Silage is more suitable in Japan, where the weather is rainy and humid in spring and summer (when reed is harvested) [6]. However, 
the quality of fermented reed silage has been shown to be poor and not optimal for storage and feeding (its $\mathrm{pH}$ is $>4.3$ [7]). Its quality would also have to be improved before it could be used as roughage.

Usually, the poor quality of silage is due to its inherent moisture, fermentable carbohydrate content, and the presence of lactic acid bacteria (LAB) $[8,9]$. In addition, harvest time within a year and $\mathrm{N}$ fertilization rate may affect silage quality by changing chemical composition in grasses $[6,10]$. However, to the best of our knowledge, there is limited information on the factors causing the poor quality of reed silage. Silage additives are widely used for improving silage fermentation, which include $\mathrm{LAB}$, a substrate such as molasses for $\mathrm{LAB}$ growth, and cellulases. The use of cellulase at ensiling has been used to enhance fiber degradation and produce substrates, such as water-soluble carbohydrates (WSC) [11]. Therefore, the use of LAB, WSC, and cellulase at ensiling are expected to improve the fermentation quality of common reed silage.

In this study, we conducted two experiments to investigate the factors responsible for poor quality of reed silage and investigate potentially useful additives for improving its quality. The aims of Experiment 1 were to identify the indigenous populations of LAB in common reed, quantify reed's WSC content, and compare the quality of fermented silage by adding $\mathrm{LAB}$ or/and glucose to the silage without additives. The aims of Experiment 2 were to investigate the effects of various reed-management strategies on fermented reed quality, including harvest times, varying $\mathrm{N}$ fertilization rates, and the addition of LAB and cellulase at ensiling.

\section{MATERIALS AND METHODS}

\section{Experimental site and reed management}

Experiment 1: Reed was collected from an abandoned paddy field $(10 \mathrm{~m} \times 10 \mathrm{~m})$ located on reclaimed land in Kahokugata, Kanazawa, Ishikawa Prefecture ( $\left.36^{\circ} 40^{\prime} \mathrm{N}, 136^{\circ} 41^{\prime} \mathrm{E}\right)$. On 20 April 2010, all plants and withered residues were cut using a bush cutter and removed from the field. On 20 May, springgrown reed was cut at a height of approximately $10 \mathrm{~cm}$ above the ground using hand sickles and collected. The collected reed was finely chopped with a hay cutter (22-mm cutting length) for silage preparation and then subjected to indigenous LAB analysis. Portions of the chopped grass were oven dried at $60^{\circ} \mathrm{C}$ for $24 \mathrm{~h}$ for chemical composition analyses. On 3 August, summer-grown reed was harvested (using the same methods as above) after cutting and removing all plants on 25 June. Indigenous LAB populations were analyzed from the summer-grown reed.

Experiment 2: Reed was collected from a dry riverbed in Kahokugata $\left(36^{\circ} 49^{\prime} \mathrm{N}, 136^{\circ} 40^{\prime} \mathrm{E}\right)$. The collection field, dominated by reed, had been managed for about 40 years by cutting the reed once per year to keep the river channels clear. Twelve plots ( $3 \mathrm{~m} \times 3 \mathrm{~m})$ were established in an experimental area (17 $\mathrm{m} \times 22 \mathrm{~m}$ ) of the field on 19 April 2014, after cutting and removing all plants growing in the area. Four $\mathrm{N}$ fertilization treatments (with three replicates per treatment) were randomly assigned to the $9-\mathrm{m}^{2}$ plots: $0 \mathrm{~g} \mathrm{~N} / \mathrm{m}^{2}(0 \mathrm{~N}), 4 \mathrm{~g} \mathrm{~N} / \mathrm{m}^{2}(4 \mathrm{~N}), 8$ $\mathrm{g} \mathrm{N} / \mathrm{m}^{2}(8 \mathrm{~N})$, and $12 \mathrm{~g} \mathrm{~N} / \mathrm{m}^{2}(12 \mathrm{~N})$. N fertilizer (14\% N, $14 \%$ $\mathrm{P}_{2} \mathrm{O}_{5}$, and $14 \% \mathrm{~K}_{2} \mathrm{O}$ ) was top-dressed (surface spread) in each plot after all plants had been removed. Reed was harvested three times (25 May, 27 June, and 31 July 2014) from $1 \mathrm{~m} \times 1 \mathrm{~m}$ subplots within each 9-m2 plot. Reed was harvested using sickles, at a height of approximately $10 \mathrm{~cm}$ above ground. At each harvest, all plants in the plots (and experimental area) were cut using a bush cutter and removed from the area before adding $\mathrm{N}$ fertilizer. The collected reed was finely chopped with a hay cutter for silage preparation. Portions of the chopped grass were oven dried for chemical composition analyses.

\section{LAB analysis}

The common reed collected in Experiment 1 (20 May and 3 August 2010) was immediately classified into the following three groups based on height: $\leq 0.5 \mathrm{~m}$ (short-statured), 0.5 to $1.0 \mathrm{~m}$ (mid-statured), and $\geq 1.0 \mathrm{~m}$ (tall-statured). Reed in each group was cut using sterilized scissors to a length of $1 \mathrm{~cm}$ for indigenous LAB analysis. A $10 \mathrm{~g}$ portion of the cut reed was blended with $90 \mathrm{~mL}$ of sterilized distilled water. Serial dilutions were plated on de Man, Rogosa and Sharpe (MRS) agar plates (Difco Laboratories, Detroit, MI, USA). The agar plates were then incubated in an anaerobic vessel at $30^{\circ} \mathrm{C}$ for $48 \mathrm{~h}$. The grown colonies were grouped by their shapes and colors and counted as colony forming units (CFUs). Representative colonies were cultivated in $4 \mathrm{~mL}$ of MRS medium at $30^{\circ} \mathrm{C}$ overnight and used for species identification. Genomic DNA was extracted, according to the manufacturer's instructions, using the Wizard Genomic DNA Extraction Kit (Promega, Fitchburg, MA, USA). Whole regions of the 16S ribosomal RNA gene (rDNA) were amplified with Ex Taq DNA Polymerase (Takarabio, Shiga, Japan) using F7 (5'-AGAGTTTGA TYMTGGCTCAG-3') and R1510 (5'-ACGGYTACCTTGT TACGACTT- $3^{\prime}$ ) as polymerase chain reaction (PCR) primers. The amplified fragments were purified using the QIAquick PCR Purification Kit (Qiagen, Venlo, Netherlands). The PCR protocol was as follows: $96^{\circ} \mathrm{C}$ for $2 \mathrm{~min}$, followed by 25 cycles of denaturation at $96^{\circ} \mathrm{C}$ for $15 \mathrm{~s}$, primer annealing at $50^{\circ} \mathrm{C}$ for $15 \mathrm{~s}$, and extension at $72^{\circ} \mathrm{C}$ for $1.5 \mathrm{~min}$. The sequencing reaction was performed using the BigDye XTerminator Purification Kit (Applied Biosystems, Carlsbad, CA, USA) and DNA sequences were analyzed using the 3130xl Genetic Analyzer (Applied Biosystems, USA). Nucleotide sequences of multiple, hyper-variable regions of $16 \mathrm{~S}$ rDNA genes were analyzed and bacterial species were identified according to the GenBank database using the BLAST program at the National Center for Biotechnology Information. 


\section{Silage preparation}

Experiment 1: Four silage treatments were prepared as follows: no-additives (NA treatment), $2 \%$ glucose on a fresh matter (FM) basis ( $\mathrm{G}$ treatment), $0.0017 \%$ LAB (Lactobacillus plantarum Chikuso-1; Snow Bland Seed Co., Hokkaido, Japan) on an FM basis (L treatment), and glucose plus LAB addition ( $\mathrm{G}+\mathrm{L}$ treatment). A glucose solution $(1 \mathrm{~g} / \mathrm{mL}$ distilled water) was prepared by heating it at $40^{\circ} \mathrm{C}$. Reed ( $\left.100 \mathrm{~g} \mathrm{FM}\right)$ of the $\mathrm{G}$, $\mathrm{L}$, and $\mathrm{G}+\mathrm{L}$ treatments were mixed with a $2 \mathrm{~mL}$ glucose solution and $1 \mathrm{~mL}$ distilled water, a $1 \mathrm{~mL}$ of LAB solution $(0.0017 \mathrm{~g} / \mathrm{mL}$ distilled water) and $2 \mathrm{~mL}$ distilled water, and a $2 \mathrm{~mL}$ glucose solution and $1 \mathrm{~mL}$ of LAB solution, respectively. The volume of water addition in the NA treatment was an equivalent amount $(3 \mathrm{~mL})$ of distilled water. Then, $100 \mathrm{~g}$ of each of these mixtures was packed into plastic pouches (Hiryu KN; Asahi Kasei, Tokyo, Japan) and vacuum-sealed. Five replicate pouches were prepared for each treatment; all the pouches were stored for two months at room temperature $\left(18^{\circ} \mathrm{C}\right.$ to $\left.22^{\circ} \mathrm{C}\right)$.

Experiment 2: Two silage treatments for each $\mathrm{N}$ treatment were prepared as follow: no-additives (NA treatment) and $0.0017 \%$ commercial additive (Si Master AC; Snow Bland Seed Co., Hokkaido, Japan) that contained acremonium cellulase and LAB (Lactobacillus paracasei and Lactococcus lactis) on a FM basis (CL treatment). The additive solution (6.8\% commercial additive) was added to the reed in the CL treatment. Reed of the NA treatment were supplemented with the same amount of distilled water as that used for the CL treatment. Then, $100 \mathrm{~g}$ of each mixture was packed into plastic pouches and sealed. Six pouches (three replicate pouches from NA and CL, respectively) were prepared from reed in each experimental plot. All pouches were stored for two months at room temperature $\left(18^{\circ} \mathrm{C}\right.$ to $\left.22^{\circ} \mathrm{C}\right)$.

\section{Chemical analyses}

The DM, crude ash (CA), and ether extract (EE) were determined following the method described in Abe [12]. Crude protein $(\mathrm{CP})$ was determined with a nitrogen and carbon analyzer (Sumigraph Model NL-220F; Sumika Chemical Analysis Service, Tokyo, Japan). The organic cellular contents (OCC), nitrogen-cell wall free extract (NCWFE), organic cell wall (OCW), organic a (Oa; high-digestible fraction in OCW), and organic $\mathrm{b}(\mathrm{Ob}$; low-digestible fraction in $\mathrm{OCW})$ were determined by a feed analysis based on the enzymatic method $[13,14]$.

The $\mathrm{pH}$ and organic acids of silage were determined using the method described by Cai [15] with slight modifications. Silage was cut to a length of approximately $5 \mathrm{~mm}$ using scissors, and then $50 \mathrm{~g}$ of the cut silage was mixed with $140 \mathrm{~mL}$ of distilled water and then stored for $24 \mathrm{~h}$ at $4^{\circ} \mathrm{C}$. After $24 \mathrm{~h}$, the mixture was filtered through four layers of gauze. The $\mathrm{pH}$ of the filtrate was determined using a glass-electrode $\mathrm{pH}$ meter
(F-52; Horiba, Tokyo Japan). The filtrate was centrifuged at $1,600 \times \mathrm{g}$ for $15 \mathrm{~min}$ and the supernatant was used for the analysis of ammonia-nitrogen $\left(\mathrm{NH}_{3}-\mathrm{N}\right)$. The $\mathrm{NH}_{3}-\mathrm{N}$ content was determined according to the indophenol method [16]. The supernatant was filtered using a disposable membrane filter (DISMIC 13CP045AN; ADVANTEC, Tokyo, Japan) and the filtrate was used to determine organic acid content. The lactic acid, acetic acid, propionic acid, and butyric acid contents in the filtrate were determined using high performance liquid chromatography (Prominence Organic Acid Analysis System; Shimadzu, Kyoto, Japan).

\section{Statistical analyses}

All statistical analyses were performed using SPSS 18 for Windows (SPSS Japan Inc., Tokyo, Japan). Differences in the fermentative parameters of reed silage in Experiment 1 were evaluated by one-way analysis of variance (ANOVA) using the general linear model procedure and then means were separated based on Tukey's Honest Significant Difference test. In Experiment 2, the effects of harvest time, $\mathrm{N}$ fertilization, and additive use on the chemical composition in reed and quality of fermented reed silage were evaluated with a repeated measure ANOVA. Means were separated based on the Bonferroni procedure. The association between variables indicating the quality of fermented reed silage and chemical composition in reed was evaluated with correlation analyses. All analyses used $\mathrm{p}<0.05$ as a criterion of statistical significance.

\section{RESULTS}

\section{Experiment 1}

Two LAB species, Carnobacterium maltaromaticum (C. maltaromaticum) and Enterococcus sulfurous (E. sulfurous), were identified from the isolated colonies (Table 1); the other species identified were non-LAB species (Staphylococcus spp., Listeria spp., and Bacillus spp.). No LAB species were detected from the mid- and tall-statured reeds harvested in either May or August (spring-grown reed or summer-grown reed). The concentration of C. maltaromaticum in small-statured reed harvested in May was $2.26 \log$ CFU/g FM. The concentration of $E$. sulfureus in small-statured reed harvested in August was $2.00 \log \mathrm{CFU} / \mathrm{g}$ FM. In our experiment, the duration of reed growth harvested for ensilage was 31 days. The WSC content was $53 \mathrm{~g} / \mathrm{kg}$ DM (Table 2) and the values on a DM and FM basis were $5.3 \%$ and $0.9 \%$, respectively.

The $\mathrm{pH}$, acetic acid, and $\mathrm{NH}_{3}-\mathrm{N}$ concentrations in the $\mathrm{NA}$ treatment were the highest among all the treatments, while lactic acid content was very low (Table 3 ). The $\mathrm{pH}$, lactic acid, acetic acid, and butyric acid concentrations did not significantly differ between the NA and L treatments $(\mathrm{p} \geq 0.05)$. The $\mathrm{pH}$, acetic acid, propionic acid, and $\mathrm{NH}_{3}-\mathrm{N}$ concentrations were significantly lower, while the lactic acid concentration 
Table 1. Species and numbers of indigenous $L A B$ in the common reed from Experiment 1

\begin{tabular}{lcccc}
\hline $\begin{array}{c}\text { Harvested } \\
\text { month }\end{array}$ & $\begin{array}{c}\text { Plant } \\
\text { size }(\mathbf{m})\end{array}$ & $\begin{array}{c}\text { Identified LAB } \\
\text { species }\end{array}$ & $\begin{array}{c}\text { 16S rDNA } \\
\text { similarity } \\
(\%)\end{array}$ & $\begin{array}{c}\text { The number of } \\
\text { bacteria } \\
\text { (log CFU/g FM) }\end{array}$ \\
\hline May & $\leq 0.5$ & $\begin{array}{c}\text { Carnobacterium } \\
\text { maltaromaticum }\end{array}$ & 100 & 2.26 \\
& $0.5-1.0$ & ND & - & - \\
August & $\geq 1.0$ & ND & - & - \\
& $\leq 0.5$ & $\begin{array}{c}\text { Enterococcus } \\
\text { sulfureus }\end{array}$ & 100 & 2.00 \\
& $0.5-1.0$ & ND & - & - \\
& $\geq 1.0$ & ND & - & - \\
\hline
\end{tabular}

$\overline{L A B}$, lactic acid bacteria; CFU, colony forming unit; FM, fresh mater; ND, not detected.

was significantly higher in the $\mathrm{G}$ treatment than in the $\mathrm{L}$ and NA treatments $(\mathrm{p}<0.05)$. The $\mathrm{pH}$, acetic acid, butyric acid, and $\mathrm{NH}_{3}-\mathrm{N}$ concentrations were significantly lower, while the lactic acid concentration was significantly higher in the G+L treatment than in the NA, G, and $\mathrm{L}$ treatments $(\mathrm{p}<0.05)$. The $\mathrm{pH}$ and lactic acid content in the $\mathrm{G}+\mathrm{L}$ treatment were 3.90 and $14.19 \mathrm{~g} / \mathrm{kg}$ FM, respectively.

\section{Experiment 2}

The duration of pre-harvest growth for reed were 35, 34, and 35 days at the first, second, and third harvests, respectively. Except for $\mathrm{CP}$, the chemical composition of reed was not affected by $\mathrm{N}$ fertilization ( $\mathrm{p} \geq 0.05$; Table 4$)$. However, $\mathrm{CP}$ content was significantly increased by $\mathrm{N}$ fertilization $(\mathrm{p}<0.01)$. $\mathrm{CP}$ content in the $8 \mathrm{~N}$ and $12 \mathrm{~N}$ treatments was significantly higher than it was in the $0 \mathrm{~N}$ and $4 \mathrm{~N}$ treatments $(\mathrm{p}<0.05)$ (Table 5). Except for $\mathrm{Oa}$, chemical composition was significantly affected by harvest time within a year $(\mathrm{p}<0.001$; Table 4$)$. Moisture, organic matter (OM), OCC, CP, EE, and NCWFE contents from reed collected at the third harvest were significantly lower than from reed collected at the first and second

Table 2. Chemical composition (g/kg DM) of the common reed from Experiment 1

\begin{tabular}{lc}
\hline Items & \\
\hline Moisture (g/kg FM) & 817 \\
Organic matter & 886 \\
Organic cellular contents & 236 \\
Crude protein & 177 \\
Ether extract & 42 \\
Nitrogen cell wall-free extract & 43 \\
Organic cell wall & 651 \\
Organic a fraction & 135 \\
Organic b fraction & 516 \\
Water-soluble carbohydrate & 53 \\
Glucose & 11 \\
Sucrose & 2 \\
Fructose & 40 \\
\hline
\end{tabular}

DM, dry matter; FM, fresh matter. harvests $(\mathrm{p}<0.05)$. Mean CP content at the first, second, and third harvests were 204, 185, and $179 \mathrm{~g} / \mathrm{kg} \mathrm{DM}$, respectively (Table 5). The mean moisture content at the first, second, and third harvest was 803,784 , and $763 \mathrm{~g} / \mathrm{kg} \mathrm{FM}$, respectively. The mean NCWFE content at the first, second, and third harvest was $64.46,49.77$, and $16.43 \mathrm{~g} / \mathrm{kg} \mathrm{DM}$, respectively. OCW and $\mathrm{Ob}$ were significantly different among the three harvest times and frequent harvesting significantly increased mean $\mathrm{Ob}$ content $(\mathrm{p}<0.05)$. Oa content in reed was not affected by either $\mathrm{N}$ fertilization or harvest time within a year $(\mathrm{p} \geq 0.05)$. In this experiment, there were no interactions between $\mathrm{N}$ fertilization and harvest time relative to the chemical composition of reed ( $\mathrm{p} \geq 0.05$; Table 4 ).

Moisture, $\mathrm{pH}, \mathrm{NH}_{3}-\mathrm{N}$, lactic acid, acetic acid, and propionic acid of reed silage were not significantly affected by $\mathrm{N}$ fertilization ( $\mathrm{p} \geq 0.05$; Table 4$)$. However, butyric acid was significantly reduced following $\mathrm{N}$ fertilization $(\mathrm{p}<0.05)$. The butyric acid content significantly decreased from $1.44 \mathrm{~g} / \mathrm{kg}$ in the $0 \mathrm{~N}$ treatment to $0.78 \mathrm{~g} / \mathrm{kg} \mathrm{FM}$ in the $12 \mathrm{~N}$ treatment ( $\mathrm{p}<0.05$; Table 6 ). Moisture and $\mathrm{pH}$ of the silage were related to both harvest time of reed within a year and use (at ensiling) of the additive containing cellulase and LAB $(\mathrm{p}<0.05$; Table 4$)$. The mean moisture content decreased by frequent harvesting $(\mathrm{p}<0.05$; Table 7). The mean moisture content of the NA and CL treatments was 772 and $756 \mathrm{~g} / \mathrm{kg} \mathrm{FM}$, respectively, which decreased with the use of the additive $(\mathrm{p}<0.05)$. The $\mathrm{pH}$ of the silage increased with increasing frequency of harvest $(\mathrm{p}<0.05)$. The $\mathrm{pH}$ of the NA and CL treatments decreased with the use of the additive $(\mathrm{p}<0.05)$. Propionic acid was significantly affected by both harvest time within a year and use of the additive $(\mathrm{p}<0.01$; Table 7).

Lactic acid in the silage was significantly affected by the interaction of harvest time and use of the additive $(p<0.001$; Table 4). Lactic acid content of the CL treatment was lower at the third harvest relative to the first harvest ( $<<0.05$; Table 7). In contrast, lactic acid content in the NA treatment was higher at the third (and second) harvests relative to the first

Table 3. Fermentation quality ( $\mathrm{g} / \mathrm{kg} \mathrm{FM}$ ) of treated and non-treated reed silage from Experiment 1

\begin{tabular}{lcccccc}
\hline Items & $\mathrm{NA}$ & $\mathbf{G}^{1)}$ & $\mathbf{L}^{1)}$ & $\mathbf{G}^{1} \mathbf{L}^{1)}$ & $\mathrm{SEM}$ & p-value \\
\hline Moisture (g/kg FM) & $825^{\mathrm{a}}$ & $809^{\mathrm{bc}}$ & $819^{\mathrm{ab}}$ & $799^{\mathrm{c}}$ & 2.67 & $<0.001$ \\
pH & $5.16^{\mathrm{a}}$ & $4.63^{\mathrm{b}}$ & $5.13^{\mathrm{a}}$ & $3.90^{\mathrm{c}}$ & 0.12 & $<0.001$ \\
Lactic acid & $0.30^{\mathrm{c}}$ & $6.25^{\mathrm{b}}$ & $0.44^{\mathrm{c}}$ & $14.19^{\mathrm{a}}$ & 1.33 & $<0.001$ \\
Acetic acid & $10.08^{\mathrm{a}}$ & $5.28^{\mathrm{b}}$ & $9.38^{\mathrm{a}}$ & $2.26^{\mathrm{c}}$ & 0.77 & $<0.001$ \\
Propionic acid & $4.03^{\mathrm{a}}$ & $0.85^{\mathrm{c}}$ & $2.68^{\mathrm{b}}$ & $0.36^{\mathrm{c}}$ & 0.34 & $<0.001$ \\
Butyric acid & $3.93^{\mathrm{a}}$ & $2.94^{\mathrm{a}}$ & $4.44^{\mathrm{a}}$ & $0.03^{\mathrm{b}}$ & 0.48 & 0.001 \\
$\mathrm{NH}_{3}-\mathrm{N}$ & $2.33^{\mathrm{a}}$ & $1.02^{\mathrm{c}}$ & $2.05^{\mathrm{b}}$ & $0.35^{\mathrm{d}}$ & 0.18 & $<0.001$ \\
\hline
\end{tabular}

FM, fresh matter; NA, no-additives treatment; SEM, standard error of the mean.

1) $G, L$, and $G+L$ indicate the treatments applied glucose, lactic acid bacteria, and glucose plus lactic acid bacteria, respectively.

${ }^{a-c}$ Means with different superscripts in the same row indicate significant differences $(p<0.05)$. 
Table 4. Significance ( $p$-value) of main effects and interactions of $N$ fertilization, harvest time within a year, and use of an additive at ensiling in Experiment 2

\begin{tabular}{|c|c|c|c|c|c|c|c|}
\hline \multirow{2}{*}{ Items } & \multicolumn{3}{|c|}{ Effect } & \multicolumn{4}{|c|}{ Interaction } \\
\hline & $\mathrm{N}$ & $\mathrm{H}$ & A & $\mathrm{N} \times \mathrm{H}$ & $\mathrm{N} \times \mathrm{A}$ & $\mathrm{H} \times \mathrm{A}$ & $\mathrm{N} \times \mathrm{H} \times \mathrm{A}$ \\
\hline \multicolumn{8}{|c|}{$p$-value } \\
\hline \multicolumn{8}{|c|}{ Chemical composition } \\
\hline Moisture & 0.550 & $<0.001$ & - & 0.321 & - & - & - \\
\hline $\mathrm{OM}$ & 0.083 & $<0.001$ & - & 0.420 & - & - & - \\
\hline OCC & 0.238 & $<0.001$ & - & 0.548 & - & - & - \\
\hline$C P$ & 0.002 & $<0.001$ & - & 0.179 & - & - & - \\
\hline $\mathrm{EE}$ & 0.055 & $<0.001$ & - & 0.117 & - & - & - \\
\hline NCWFE & 0.199 & $<0.001$ & - & 0.155 & - & - & - \\
\hline OCW & 0.367 & $<0.001$ & - & 0.556 & - & - & - \\
\hline $\mathrm{Oa}$ & 0.359 & 0.646 & - & 0.615 & - & - & - \\
\hline $\mathrm{Ob}$ & 0.474 & $<0.001$ & - & 0.885 & - & - & - \\
\hline \multicolumn{8}{|c|}{ Fermentation quality } \\
\hline Moisture & 0.911 & $<0.001$ & 0.037 & 0.098 & 0.979 & 0.282 & 0.836 \\
\hline $\mathrm{pH}$ & 0.464 & $<0.001$ & $<0.001$ & 0.250 & 0.811 & 0.981 & 0.505 \\
\hline Lactic acid & 0.738 & 0.807 & $<0.001$ & 0.174 & 0.911 & $<0.001$ & 0.072 \\
\hline Acetic acid & 0.317 & 0.065 & $<0.001$ & 0.012 & 0.714 & 0.008 & 0.163 \\
\hline Propionic acid & 0.146 & $<0.001$ & $<0.001$ & 0.314 & 0.299 & 0.111 & 0.221 \\
\hline Butyric acid & 0.040 & $<0.001$ & $<0.001$ & 0.628 & 0.283 & $<0.001$ & 0.796 \\
\hline $\mathrm{NH}_{3}-\mathrm{N}$ & 0.814 & 0.043 & $<0.001$ & 0.393 & 0.892 & 0.002 & 0.717 \\
\hline
\end{tabular}

$\mathrm{N}$, nitrogen fertilization; $\mathrm{H}$, harvest time within a year; $\mathrm{A}$, use of the additive containing cellulase and lactic acid bacteria; OM, organic matter; OCC, organic cellular contents; $C P$, crude protein; $E E$, ether extract; NCWFE, nitrogen cell wall free extracts; $O C W$, organic cell wall; $O a$, organic $a$; $O b$, organic $b$.

Table 5. Chemical composition ( $\mathrm{g} / \mathrm{kg} \mathrm{DM}$ ) of the common reed from Experiment 2 subjected to $\mathrm{N}$ fertilization and frequent harvesting

\begin{tabular}{|c|c|c|c|c|c|c|c|c|c|c|c|c|c|}
\hline \multirow{2}{*}{ Items } & \multicolumn{3}{|c|}{$0 \mathrm{~g} \mathrm{~N} / \mathrm{m}^{2}$} & \multicolumn{3}{|c|}{$4{\mathrm{~g} \mathrm{~N} / \mathrm{m}^{2}}^{2}$} & \multicolumn{3}{|c|}{$8 \mathrm{~g} \mathrm{~N} / \mathrm{m}^{2}$} & \multicolumn{3}{|c|}{$12 \mathrm{~g} \mathrm{~N} / \mathrm{m}^{2}$} & \multirow{2}{*}{ SEM } \\
\hline & First & Second & Third & First & Second & Third & First & Second & Third & First & Second & Third & \\
\hline Moisture (g/kg FM) & 800 & 771 & 752 & 799 & 786 & 771 & 804 & 788 & 757 & 809 & 791 & 766 & 3.65 \\
\hline $\mathrm{OM}$ & 894 & 897 & 885 & 886 & 887 & 873 & 885 & 877 & 867 & 885 & 882 & 872 & 1.75 \\
\hline OCC & 265 & 250 & 200 & 257 & 206 & 185 & 264 & 231 & 188 & 275 & 250 & 192 & 6.19 \\
\hline $\mathrm{CP}$ & 201 & 172 & 159 & 193 & 174 & 163 & 207 & 200 & 198 & 213 & 195 & 197 & 3.23 \\
\hline EE & 26 & 28 & 26 & 27 & 26 & 23 & 27 & 30 & 26 & 28 & 29 & 26 & 0.32 \\
\hline NCWFE & 67.21 & 76.08 & 40.42 & 65.84 & 32.67 & 24.26 & 59.93 & 35.44 & 1.01 & 64.84 & 54.89 & 0.01 & 5.02 \\
\hline OCW & 629 & 648 & 686 & 628 & 680 & 688 & 621 & 647 & 679 & 610 & 632 & 681 & 5.60 \\
\hline $\mathrm{Oa}$ & 93 & 75 & 98 & 99 & 108 & 94 & 100 & 99 & 98 & 88 & 80 & 90 & 2.89 \\
\hline$O b$ & 536 & 572 & 588 & 529 & 572 & 595 & 521 & 548 & 581 & 522 & 552 & 591 & 5.26 \\
\hline
\end{tabular}

$\mathrm{DM}$, dry matter; SEM, standard error of the mean; FM, fresh matter; OM, organic matter; OCC, organic cellular contents; CP, crude protein; EE, ether extract; NCWFE, nitrogen cell wall free extracts; $0 C W$, organic cell wall; $0 a$, organic a; $0 b$, organic $b$.

Table 6. Fermentation quality ( $\mathrm{g} / \mathrm{kg} \mathrm{FM}$ ) of common reed silage in Experiment 2 following $N$ fertilizer application at four rates

\begin{tabular}{lccccc}
\hline \multirow{2}{*}{ Items } & \multicolumn{4}{c}{$\mathbf{N}$ fertilization level $\left(\mathbf{g ~ N} / \mathbf{m}^{2}\right)$} & \multirow{2}{*}{ SEM } \\
\cline { 2 - 5 } & $\mathbf{0}$ & $\mathbf{4}$ & $\mathbf{8}$ & $\mathbf{1 2}$ & \\
\hline Moisture (g/kg FM) & 760 & 763 & 765 & 767 & 3.24 \\
$\mathrm{pH}$ & 5.29 & 5.42 & 5.48 & 5.25 & 0.10 \\
Lactic acid & 6.52 & 5.72 & 5.53 & 6.42 & 0.40 \\
Acetic acid & 4.27 & 4.62 & 4.17 & 3.60 & 0.22 \\
Propionic acid & 0.54 & 0.52 & 0.49 & 0.43 & 0.03 \\
Butyric acid & $1.44^{\mathrm{a}}$ & $1.37^{\mathrm{ab}}$ & $1.12^{\mathrm{ab}}$ & $0.78^{\mathrm{b}}$ & 0.19 \\
$\mathrm{NH}_{3}-\mathrm{N}$ & 0.85 & 0.86 & 0.84 & 0.78 & 0.04 \\
\hline
\end{tabular}

FM, fresh matter; SEM, standard error of the mean.

${ }^{a b}$ Means with different superscripts in the same row indicate significant differences $(p<0.05)$. harvest $(\mathrm{p}<0.05)$. Mean lactic acid content increased with the use of the additive $(\mathrm{p}<0.05)$ : lactic acid content was 4.02 and $8.07 \mathrm{~g} / \mathrm{kg}$ FM in the NA and CL treatments, respectively. Acetic acid, butyric acid, and $\mathrm{NH}_{3}-\mathrm{N}$ were significantly related to the interaction of harvest time and use of the additive $(\mathrm{p}<0.05$; Table 4$)$. Use of the additive was significantly and negatively related to the mean contents of acetic acid (5.64 to $2.69 \mathrm{~g} / \mathrm{kg} \mathrm{FM}$ ), butyric acid (2.04 to $0.31 \mathrm{~g} / \mathrm{kg} \mathrm{FM}$ ), and $\mathrm{NH}_{3}-\mathrm{N}$ ( 1.12 to $0.54 \mathrm{~g} / \mathrm{kg} \mathrm{FM})(\mathrm{p}<0.05$; Table 7$)$. Acetic acid and $\mathrm{NH}_{3}-\mathrm{N}$ contents in the $\mathrm{CL}$ treatment were higher at the second and/or third harvest relative to the first harvest $(p<0.05)$. The acetic acid of the NA treatment did not significantly differ among the three harvests $(\mathrm{p} \geq 0.05)$. The butyric acid and $\mathrm{NH}_{3}$ - 
Table 7. Fermentation quality ( $\mathrm{g} / \mathrm{kg} \mathrm{FM)} \mathrm{of} \mathrm{common} \mathrm{reed} \mathrm{silage} \mathrm{at} \mathrm{the} \mathrm{first,} \mathrm{second,} \mathrm{and} \mathrm{third} \mathrm{harvests} \mathrm{from} \mathrm{Experiment} 2$

\begin{tabular}{|c|c|c|c|c|c|c|c|c|c|c|}
\hline \multirow{2}{*}{ Items } & \multicolumn{3}{|c|}{ NA } & \multirow{2}{*}{ Mean } & \multirow{2}{*}{ SEM } & \multicolumn{3}{|c|}{$\mathrm{CL}$} & \multirow{2}{*}{ Mean } & \multirow{2}{*}{ SEM } \\
\hline & First & Second & Third & & & First & Second & Third & & \\
\hline Moisture (g/kg FM) & $802^{\mathrm{a}}$ & $764^{b}$ & $749^{b}$ & 772 & 4.60 & $781^{a}$ & $751^{\mathrm{ab}}$ & $736^{b}$ & 756 & 4.23 \\
\hline $\mathrm{pH}$ & $5.71^{b}$ & $6.12^{\mathrm{a}}$ & $6.33^{\mathrm{a}}$ & 6.05 & 0.08 & $4.31^{b}$ & $4.75^{\mathrm{a}}$ & $4.95^{\mathrm{a}}$ & 4.67 & 0.08 \\
\hline Lactic acid & $2.04^{b}$ & $4.28^{a}$ & $5.74^{\mathrm{a}}$ & 4.02 & 0.46 & $9.67^{\mathrm{a}}$ & $8.13^{\mathrm{ab}}$ & $6.42^{b}$ & 8.07 & 0.45 \\
\hline Acetic acid & 5.82 & 5.31 & 5.78 & 5.64 & 0.22 & $2.06^{b}$ & $2.90^{b}$ & $3.13^{\mathrm{a}}$ & 2.69 & 0.17 \\
\hline Propionic acid & $0.85^{\mathrm{a}}$ & $0.57^{b}$ & $0.57^{\mathrm{b}}$ & 0.66 & 0.04 & 0.41 & 0.29 & 0.28 & 0.32 & 0.02 \\
\hline Butyric acid & $4.39^{\mathrm{a}}$ & $0.86^{b}$ & $0.88^{b}$ & 2.04 & 0.31 & 0.10 & 0.37 & 0.45 & 0.31 & 0.10 \\
\hline $\mathrm{NH}_{3}-\mathrm{N}$ & $1.25^{\mathrm{a}}$ & $1.10^{\mathrm{ab}}$ & $1.01^{b}$ & 1.12 & 0.44 & $0.42^{b}$ & $0.71^{\mathrm{a}}$ & $0.50^{b}$ & 0.54 & 0.34 \\
\hline
\end{tabular}

FM, fresh matter; NA, no-additives treatment; $\mathrm{CL}$, treatment applied cellulase and lactic acid bacteria; SEM, standard error of the mean.

${ }^{\mathrm{ab}}$ Means within the same silage treatment in the same row with different letters denote a significant difference $(p<0.05)$.

$\mathrm{N}$ contents of the NA treatment were lower following more frequent harvesting $(\mathrm{p}<0.05)$. In the $\mathrm{CL}$ treatment, $\mathrm{pH}$, lactic acid, and acetic acid of silage were correlated with NCWFE in reed (Figure 1). Negative correlations between the NCW$\mathrm{FE}$ and $\mathrm{pH}(\mathrm{r}=-0.513 ; \mathrm{p}<0.05)$ and acetic acid $(\mathrm{r}=-0.422$; $\mathrm{p}<0.05)$ were detected; in contrast, a positive correlation between the NCWFE and lactic acid was detected $(r=0.568$; $\mathrm{p}<0.001)$. Other chemical components in reed did not significantly correlate with the quality of the reed silage $(\mathrm{p} \geq 0.05)$.

\section{DISCUSSION}

There have been no studies indicating that C. maltaromaticum is useful for preparing silage and it has been reported that the species is a spoilage bacteria that decomposes food products, such as meat and fish [17]. Some Lactobacillus and Lactococcus species are effective as LAB for improving the fermentation quality of silage due to their high lactic acid productivity and their tolerance to acidic conditions [18]. Li and Nishino [19] reported that $E$. sulfureus was eradicated in guinea grass silage when $\mathrm{pH}$ declined from 6.12 to 5.22 at day 28 after ensiling, whereas L. plantarum increased, even under low $\mathrm{pH}$ conditions, and survived until day 120 after ensiling. The preparation of high-quality silage has been shown to be difficult when $E$. sulfureus was the only LAB in the silage. Morichi and Ohyama [20] investigated indigenous $\mathrm{LAB}$ populations in forage and reported that Lactobacillus species was not detected in approximately one-third of 201 forage samples. They also found that the number of Lactobacillus species in forage was higher in summer than in spring and autumn. In Experiment 1of our study, Lactobacillus species were not detected in reed in either spring or summer harvests. Therefore, we suspect that LAB, such as Lactobacillus species, do not exist in, or rarely inhabit common reed, at any time of the year. Moreover, the concentration of LAB in the material required to prepare high-quality silage has been found to be $\geq 5 \log \mathrm{CFU} / \mathrm{g}$ FM $[8,18]$. However, the concentration of LAB in the common reed we sampled (Experiment 1) was $<5 \log \mathrm{CFU} / \mathrm{g}$ FM. Based on all these studies, we conclude that the species and numbers of LAB normally inhabiting reed are ill-suited for preparing highquality silage from common reed.

The quality of fermented silage becomes poor when the WSC content of the material falls below $10 \%$ of DM or $2 \%$ of FM $[9,21]$. However, the WSC content of reed in our study was only $5.3 \%$ of DM and $0.9 \%$ of FM. Therefore, the WSC content in our experiment was approximately half the value required for producing good-quality silage. As a result, silage without additives ferments poorly. In general, silage with a $\mathrm{pH}$ of $\leq 4.2$ can inhibit the activity of unwanted bacteria and fungi, which in turn hinders decomposition and deterioration, which together longer stabilizes the quality of silage [22]. We found that the quality of fermented reed silage was improved more
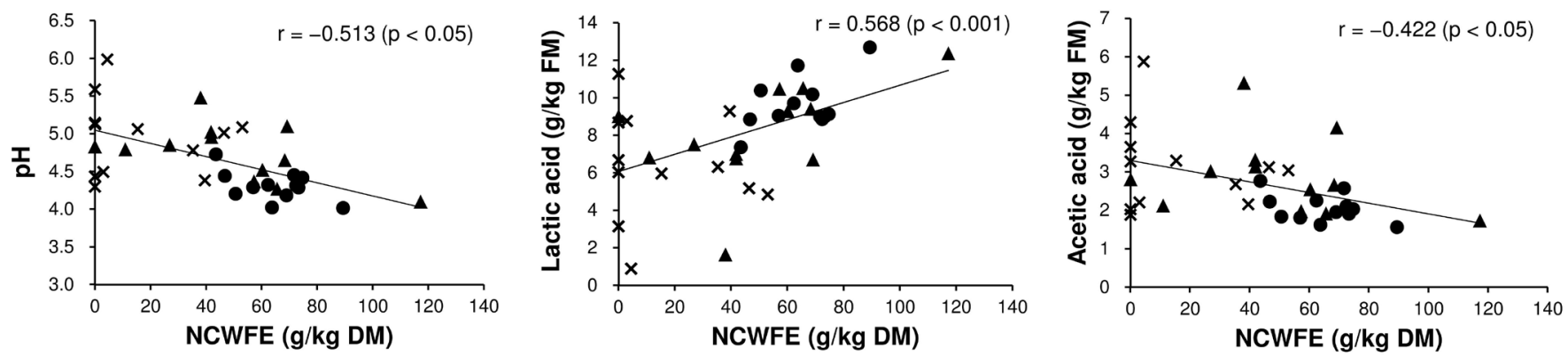

Figure 1. Relationship between the nitrogen cell wall-free extract (NCWFE) content of common reed and fermentation quality of the silage to which cellulase and lactic acid bacteria were added (the CL treatment). $\bullet$, first harvest; $\mathbf{\Delta}$, second harvest; $\times$, third harvest. 
by adding glucose than by adding $\mathrm{LAB}$ at time of ensiling. However, because the $\mathrm{pH}$ of the $\mathrm{G}$ treatment silage was 4.63, which is too high, addition of glucose alone would not be a practical choice for ensilage. In contrast, the $\mathrm{G}+\mathrm{L}$ treated silage had a higher lactic acid content, lower $\mathrm{pH}$, and lower acetic acid, butyric acid, and $\mathrm{NH}_{3}-\mathrm{N}$ contents than our other treatments. As a result, it was ideal for fermenting to silage. Therefore, we found that high-quality silage could be prepared from common reed by using two additives: LAB (such as Lactobacillus species) and a substrate (such as glucose). However, use of glucose as additive of a substrate not realistic. Because molasses is often added as a substrate additive and improve fermentation quality of silage [23], we propose that molasses used instead of glucose.

In the present study, common reed was harvested at fixed intervals to prevent extreme changes in the chemical composition that occur after growing for more than 40 days [6]. In Experiment 2, the effect of harvest time was observed for almost all the chemical components we measured, whereas the effect of $\mathrm{N}$ fertilization was only related to $\mathrm{CP}$ in reed. These results correspond with other studies in which the $\mathrm{CP}$ content of grass increased following fertilization with $\mathrm{N}[24,25]$. In general, protein is synthesized from $\mathrm{N}$ absorbed through the roots and from carbohydrates, such as WSC; therefore, a large supplement of N decreases the amount of WSC in plants due to a stimulation of carbohydrate consumption $[25,26]$. However, NCWFE, which is the non-structural carbohydrate fraction containing the WSC, was not significantly affected by $\mathrm{N}$ fertilization $(\mathrm{p}=0.199)$ in our experiment. In contrast, the effect of harvest time was significant $(\mathrm{p}<0.001)$. Common reed stores carbohydrates (produced by photosynthesis) in its rhizomes for regrowth in the following year. Some studies $[27,28]$ have reported that the carbohydrates in the rhizome of common reed decrease from spring to summer, coinciding with the peak vegetation period, and that the bulk density of rhizomes, which indicates the quantity of carbohydrate reserves, decreases when the reed is cut [29]. In our experiment, reed was harvested thrice from May to July and so we assumed that the decline in NCWFE was caused by the consumption of carbohydrates required for frequent plant regrowth. Moreover, the NCWFE content at the first and second harvest among the $\mathrm{N}$ fertilization treatments had a tendency to decrease following a high $\mathrm{N}$ fertilization rate, relative to the third harvest. The content of the third harvest was significantly low by the $12 \mathrm{~N}$ fertilization treatment. Under high $\mathrm{N}$ fertilization levels, when proteins are synthesized for regrowth, the exhaustion of carbohydrates in reed can occur. A combination of these management strategies (thrice-annual harvesting and high-N fertilization) would have an adverse effect on the sustainable use of the common reed for producing silage.

In preparing silage from Experiment 2, we found that management options that use a fertilization rate of 4 to $12 \mathrm{~g} \mathrm{~N} / \mathrm{m}^{2}$ not have a negative effect on the quality of fermented reed silage. On other hand, the effects of harvest time and use of an additive on silage quality were significant. The NA (noadditive) treated reed silage led to an increase lactic acid, a decrease in butyric acid, and the maintenance of high concentrations of acetic acid and $\mathrm{NH}_{3}-\mathrm{N}$ following frequent harvesting. These changes were likely caused by inhibiting Clostridium activity by decreasing the moisture content [8]. However, the concentration of $\mathrm{NH}_{3}-\mathrm{N}$ remained at high levels for all three harvest times and that is probably why $\mathrm{pH}$ values did not fall much (range, 5.71 to 6.33). In addition, acetic acid was at its highest concentration among the organic acids in the NA treatment. High levels of acetic acid in reed silage was observed in silages formed in response to the NA and L treatments of Experiment 1. Such fermentation has often been obtained when preparing silage from tropical grasses [30]. Even the lowest moisture conditions (third harvest) could not inhibit fermenting bacteria (enterobacteria and hetero-type LAB [8]), or prevent fermentation from producing high acetic acid concentrations and high $\mathrm{pH}$ in silage. From our analysis of the chemical compositions of our experimental treatments of reed, it was obvious that the fundamental cause for poor fermentation is a shortage of substrates, such as WSC or NCWFE, for lactic acid fermentation.

Fermentation quality of reed silage improved by adding cellulase and $\mathrm{LAB}$, which caused $\mathrm{pH}$, acetic acid, butyric acid, and $\mathrm{NH}_{3}-\mathrm{N}$ to decrease. The first harvest silage was remarkably improved by adding cellulase and LAB. However, the silage quality of the second and third harvest was lower than the first harvest and the quality of CL treatment remarkably deteriorated with frequent harvesting. From our results of correlations between fermented reed quality of the CL treatment and the chemical composition of reed as silage material (analyzed to investigate the reason(s) for the degradation in quality), we found that there was no relationship between low silage quality and high moisture content of harvested reed ( $\mathrm{p} \geq 0.05)$. On other hand, we observed a strong correlation between NCWFE and fermentation quality. We intended to supply substrates for LAB fermentation by adding cellulase. However, our results indicated that silage quality of common reed is dependent on inherent carbohydrates even when cellulase is used at ensiling, and that silage quality becomes unstable under low carbohydrate conditions. Therefore, we conclude that the cause for the reduced effectiveness of our cellulase/LAB additive at the second and third harvests was due to a lowering of $\mathrm{pH}$ exacerbated by a lack of sufficient carbohydrates immediately after ensiling.

In conclusion, preparing high-quality silage from common reed without using additives was difficult because the composition and number of indigenous LAB in reed were not suitable for maintaining lactic acid fermentation regardless of plant growth stage or season of harvest, and WSC content was so 
low. Moreover, although $\mathrm{N}$ fertilization did not negatively affect the quality of reed silage, increasing the frequency of harvest provided positive effects to the no-additive silage and negative effects to the cellulase/LAB-treated silage. The additive containing cellulase and LAB improved fermentation quality. However, to optimize silage fermentation for high-quality silage, we suggest that the most effective approach would be to add both additives LAB and a substrate to common reed silage.

\section{CONFLICT OF INTEREST}

We certify that there is no conflict of interest with any financial organization regarding the material discussed in the manuscript.

\section{ACKNOWLEDGMENTS}

We would like to thank the staff of the Kahokugata-kantakutochi-kairyouku (the office for improving Kahokugata reclaimed land) for allowing us to use the field as the experimental site and for their cooperation during the study, and Associate Professor Takashi Koyanagi and Professor Toshiki Enomoto in Ishikawa Prefectural University for their cooperation in the analysis of the indigenous bacteria and the determination of WSC in common reed. This study was financially supported by Ishikawa Prefectural University.

\section{REFERENCES}

1. Ministry of Agriculture, Forestry and Fisheries (MAFF): FY2015 Annual Report on Food, Agriculture and Rural Areas in Japan [Internet]. MAFF; 2016 [cited July 30, 2017]. Available from: http://www.maff.go.jp/e/data/publish/attach/pdf/ index-35.pdf\#search='sufficiency+rate+in+feed + Japan +27 $\% 25+2015+\mathrm{MAFF}^{\prime}$

2. Baran M, Váradyová Z, Krácčmar S, Hedbávnŷ J. The common reed (Phragmites australis) as a source of roughage in ruminant nutrition. Acta Vet Brno 2002;71:445-9.

3. Vaičekonyte R, Kiviat E, Nsenga F, Ostfeld A. An exploration of common reed (Phragmites australis) bioenergy potential in North America. Mires Peat 2014;13:1-9.

4. El-Talty YI, Abdel-Gwad MH, Mahmoud AEM. Effect of common reed (Phragmites australis) silage on performance of growing lambs. Asian J Anim Sci 2015;9:1-12.

5. Asano K, Ishikawa T, Ishida M. Digestibility of common reed (Pharagmites communis Trin.) silage as ruminant feed and effects of inclusion levels in the diet of breeding cows on feed intake, ruminal fermentation and blood metabolites. Anim Sci I 2017; 88:1955-62.

6. Asano K, Nakamura R, Araie A, et al. Effects of year and harvest time within the year on yield and chemical composition of common reed (Phragmites communis Trin.) as ruminant feed. Grassl Sci 2015;61:1-5.

7. Shahsavani A, Shojaiyan K, Saravani M, Shahraki E. A study on the effects of cellulase, xylanase and molasses enzymes on the nutritional value of common reed silage using the gas production test and dacron bags methods. Int J Sci Eng Invest 2014;3:10-5.

8. McDonald P, Henderson AR, Heron SJE. The biochemistry of silage. 2nd ed. Marlow, UK: Chalocombe Publication; 1991. p. 48-249.

9. Smith LH. Theoretical carbohydrate requirement for alfalfa silage production. Agron J 1962;54:291-3.

10. Fox JB, Brown SM. The effect of fertilizer nitrogen on silage fermentation. Grass Forage Sci 1969;24:23-4.

11. Weinberg Z, Ashbell G, Hen Y, Azrieli A. The effect of cellulase and Heicellulase plus pectinase on the aerobic stability and fiber analysis of peas and wheat silages. Anim Feed Sci Technol 1995;55:287-93.

12. Abe A. Proximate composition. In: Ishibashi T, editor. The experimental method of animal nutrition. Tokyo, Japan: Yokendo; 2001. p. 455-66 (In Japanese).

13. Abe A. Feed analysis based on carbohydrates and its application to the nutritive value of feeds. Memoirs of National Institute of Animal Industry, No.2. Tsukuba, Japan: National Institute of Animal Industry, Ministry of Agriculture, Forestry and Fisheries; 1988.

14. Abe A, Horii S, Kameoka K. Application of enzymatic analysis with glucoamylase, pronase and cellulase to various feeds for cattle. J Anim Sci 1979;48:1483-90.

15. Cai Y. Analysis method for silage. In: Japanese Society of Grassland Science, editors. Field and laboratory methods for grassland Science. Tokyo, Japan: Thsho Printing Co., Ltd.; 2004. p. 279-82.

16. Wetherburn MW. Phenol-hypochlorite reaction for determination of ammonia. Anal Chem 1967;39:971-4.

17. Laursen BG, Bay L, Cleenwerck I, et al. Carnobacterium divergens and Carnobacterium maltaromaticum as spoilers or protective cultures in meat and seafood: phenotypic and genotypic characterization. Sys Appl Microbiol 2005;28:151-64.

18. Cai Y, Benno Y, Ogawa M, Kumai S. Effect of applying lactic acid bacteria isolated from forage crops on fermentation characteristics and aerobic deterioration of silage. J Dairy Sci 1999; 82:520-6.

19.Li Y, Nishino N. Changes in the bacteria community and composition of fermentation products during ensiling of wilted Italian ryegrass and wilted guineagrass silages. Anim Sci J 2013;84:607-12.

20. Morichi T, Ohyama Y. Distribution of lactobacilli on grasses. Japan J Zootech Sci 1972;43:264-7 (In Japanese.).

21.Gordon GH, Derbyshire JC, Wiseman HG, Jacobson WC. Variations in initial composition of orchardgrass as related to silage composition and feeding value. J Dairy Sci 1964;46: 
987-92.

22.McDonald P, Whittenbury R. The silage process. In: Butler GW, Bailey RW, editors. The chemistry and biochemistry of herbage. vol. 3. London, UK: Academic Press, London and New York; 1973. p. 33-60.

23. Yunus M, Ohba N, Shimojo M, Furuse M, Masuda Y. Effects of adding urea and molasses on napiergrass silage. AsianAustralas J Anim Sci 2000;13:1542-7.

24. Keady TWJ, Mayne CS, Fitzpatrick DA. Prediction of silage feeding value from the analysis of the herbage at ensiling and effects of nitrogen fertilizer, date of harvest and additive treatment on grass silage composition. J Agric Sci 2000;134:353-68.

25. Peyraud JL, Astigarraga L. Review of the effect of nitrogen fertilization on the chemical composition, intake, digestion and nutritive value of fresh herbage: consequences on animal nutrition and N balance. Anim Feed Sci Technol 1998;72: 235-59.

26. Miller LA, Moorby JM, Davies DR, et al. Increased concentra- tion of water-soluble carbohydrate in perennial ryegrass (Lolium perenne L.): milk production from late-lactation dairy cows. Grass Forage Sci 2001;56:383-94.

27.Dinka M, Szeglet P. Carbohydrate and nutrient content in rhizomes of Phragmites australis from different habitats of Lake Fertõ/Neusiedlersee. Limnologica 1999;29:47-59.

28. Čížková H, Lukavská J, Přibáň K, Kopecký J, Brabcová H. Carbohydrate levels in rhizomes of Phragmites australis at an oligotrophic and a eutrophic site: a preliminary study. Folia Geobot 1996;31:111-8.

29. Karunaratne S, Asaeda T, Yutani K. Why is summer harvesting of common reed a viable management practice? Rep Res Edu Ctr Inlandwat Environ 2004;2:41-6.

30. Kim KH, Uchida S. Comparative studies of ensiling characteristics between temperate and tropical species. 1 . The effect of various ensiling conditions on the silage quality of Italian ryegrass (Lolium multiflorum Lam.) and Rhodegrass (Chloris gayana Kunth.). J Japan Grassl Sci 1990;36:292-9. 